Annals of Warsaw University of Life Sciences - SGGW

Land Reclamation No 47 (3), 2015: 225-236

(Ann. Warsaw Univ. of Life Sci. - SGGW, Land Reclam. 47 (3), 2015)

\title{
Shear strength of clayey soils from the vicinity of Gorlice and Ciężkowice
}

\author{
TYMOTEUSZ ZYDROŃ, EWA PRAWICA \\ Department of Hydraulic Engineering and Geotechnics, University of Agriculture in Krakow
}

\begin{abstract}
Shear strength of clayey soils from the vicinity of Gorlice and Cięzkowice. The work presents results of maximum and residual strength tests of six clayey soils from the landslide areas near Gorlice and Ciężkowice. The tests were carried out in a direct shear apparatus on samples of dimensions $60 \times 60 \mathrm{~mm}$ that were sheared at least three times. A shearing strain rate was equal $0.1 \mathrm{~mm} \cdot \mathrm{min}^{-1}$, and the range of horizontal deformation of the samples was equal $20 \%$. The results of the tests revealed that multiple shearing of the soil caused a significant decrease of its shear strength, resulting in significant changes in cohesion, and the smaller changes in the angle of internal friction. It was shown that the threetime shearing reduced the initial shear strength of about $50 \%$, and further three series of shearing decreased it approximately $15 \%$ more. The study also showed that by using a Coulomb-Mohr shear strength linear equation, the analyzed soils had a little residual cohesion. Therefore, to describe the characteristics of the residual strength, there were used two non-linear equations proposed by Mesri and Shanien (2003) and Lade (2010), which led to the same results. It was also shown that the use of non-linear characteristics of the residual strength at low values of the normal stresses gave more unfavourable results of stability calculations in relation to the method based on the linear strength characteristic taking into consideration the presence of the residual cohesion.
\end{abstract}

Key words: residual strength, clayey soils, the Outer Carpathians

\section{INTRODUCTION}

Mass movements are one of the most important engineering-geological and geotechnical problems in southern Poland. According to estimates by the PIG (Polish Geological Institute), in extreme cases 30 or even $70 \%$ of slope areas in the Carpathians is occupied by landslides (Rączkowski 2007). A significant part of the landslides are the areas that are periodically or permanently active. The Skempton's (1964) research showed that in the case of this type of mass movements the main parameter which controls the stability of slopes is the residual strength. As some authors (Borecka et al. 2006, Borecka and Kaczmarczyk 2008) observed, this issue is underestimated and overlooked in the performed stability analyses, or proposals of determination of the shear strength are too simplistic (Nowakowski et al. 1999). Existing knowledge of the residual shear strength tests in the Carpathians area is still little, mainly due to the diversity of the geological structure of the region. Therefore, the aim of this study was to determine the strength properties of selected cohesive soils.

\section{CHARACTERISTICS OF THE STUDY AREA}

The tested soils came from the area of Gorlice (Low Beskid) and Ciężkowice (Ciężkowickie Foothills). Surroundings 
of Gorlice are the region where multiple landslide processes occur, which results from a complex geological structure of the area related to the occurrence of the overthrust zone of the Magura Nappe on the Silesian unit. The soils from the vicinity of Gorlice were clayey deposits located within the Siar zone, which is the marginal zone of the Magura unit (Warchoł 2007). The soils were collected from the slopes:

- of Maślana Góra in Szymbark, from the upper part of the slope in the vicinity of Cisowy Potok;

- of Wiatrówka in Szymbark, from the lower part of the slope located in the zone of veriegated shales deposits, which are present in lower reaches of Bystrzanka stream;

- of Ropica Polska, from the middle part of the slope Ćwiercie located in the right-hand side of the valley of the Ropa river;
- located in the valley of the Siara stream in Owczary, from its left-and right-hand parts.

Red clays from the area of Ciężkowice were another tested soil. They were taken from the one of the slopes located on the right side of the river Biała valley, where a layer of menilite shales of the Silesian series occurres according to the Detailed Geological Map of Poland (Cieszkowski et al. 1987).

All the tested soils were taken from the areas where mass movements occurred in 2010. In most cases, these movements were shallow landslides which arose within the surface layers of the slopes and only the landslide on the slopes of Maślana Góra was a typical structural one.

Table 1 presents basic geotechnical properties of the tested soils. It can be noticed that the soils have very similar values of a plasticity index, falling with-

TABLE 1. Geotechnical parameters of tested soils

\begin{tabular}{|l|c|c|c|c|c|c|}
\hline Parameter & $\begin{array}{c}\text { Cięż- } \\
\text { ko- } \\
\text { wice }\end{array}$ & $\begin{array}{c}\text { Owcza- } \\
\text { ry 1 }\end{array}$ & $\begin{array}{c}\text { Owcza- } \\
\text { ry 2 }\end{array}$ & $\begin{array}{c}\text { Ropica } \\
\text { Polska }\end{array}$ & $\begin{array}{c}\text { Szymbark / } \\
\text { / Maślana } \\
\text { Góra }\end{array}$ & $\begin{array}{c}\text { Szymbark / } \\
\text { / Wiatrówki }\end{array}$ \\
\hline Fraction content [\%] & & & & & & \\
cobbles and gravel $(>2 \mathrm{~mm})$ & 0.0 & 1.4 & 0.0 & 0.0 & 0.0 & 9.9 \\
sand $(0.063-2 \mathrm{~mm})$ & 6.2 & 6.1 & 2.0 & 13.3 & 3.3 & 8.5 \\
silt $(0.002-0.063 \mathrm{~mm})$ & 47.8 & 59.5 & 65.4 & 58.9 & 71.5 & 58.6 \\
clay (<0.002 mm) & 46.0 & 33.0 & 32.6 & 27.8 & 25.2 & 22.9 \\
\hline Name of the soil acc. to & $\mathrm{Cl}$ & $\mathrm{siCl}$ & $\mathrm{siCl}$ & $\mathrm{siCl}$ & $\mathrm{siCl}$ & $\mathrm{siCl}$ \\
PN EN ISO 14688:2006 & $\mathrm{I}$ & $\mathrm{I} \pi$ & $\mathrm{I} \pi$ & $\mathrm{G} \pi \mathrm{z}$ & $\mathrm{G} \pi \mathrm{z}$ & $\mathrm{G} \pi \mathrm{z}$ \\
\hline Name of the soil acc. to & 1.84 & 1.94 & 1.99 & 1.99 & 1.87 & 1.99 \\
PN-86/B-02480 & 28.40 & 25.50 & 25.10 & 23.60 & 29.50 & 18.7 \\
\hline Bulk density [g·cm $\left.{ }^{-3}\right]$ & 27.50 & 23.80 & 25.00 & 26.60 & 31.20 & 22.4 \\
\hline Moisture content [\%] & 54.60 & 50.30 & 56.70 & 60.60 & 55.40 & 46.5 \\
\hline Plastic limit, $w_{P}[\%]$ & 27.10 & 26.50 & 31.70 & 34.00 & 24.20 & 24.1 \\
\hline Liquid limit, $w_{L}[\%]$ & 0.03 & 0.06 & 0.00 & -0.09 & -0.07 & -0.15 \\
\hline Plasticity index, $I_{P}[-]$ & & & & & \\
\hline Liquidity index, $I_{L}[-]$ & & & & \\
\hline
\end{tabular}


in the range from 24.2 to $34.0 \%$. Taking into account the moisture content and the consistency limits of the tested soils, one can observe, that they were in a firm or stiff plastic state.

\section{METHODOLOGY}

The shear strength tests were performed in the direct shear apparatus in a box of dimensions of $60 \times 60 \mathrm{~mm}$. The samples were formed at the natural moisture content to a predetermined bulk density (in accordance with the one determined in situ), subjected to a preliminary consolidation using a load in the range of $25-150 \mathrm{kPa}$ and sheared at the speed of $0.1 \mathrm{~mm} \cdot \mathrm{min}^{-1}$ to a relative deformation of $20 \%$ of the sample. After completion of the shearing, the box of the apparatus was moved back to the starting position and the soil sample was sheared again. Each sample was sheared at least three times in accordance with the recommendations of the PKN-CEN ISO/TS 17892-10, and in the cases of the soils from Ciężkowice, Maślana Góra (Szymbark) and the soil 1 from Owczary part of the samples was cut six times. During the tests, the lower box and a part of the upper one were in the water. The values of strength parameters were calculated using the method of least squares.

The test results analysis took into account the maximum value of the shear resistance obtained at the first shearing of the sample and the residual shear strength, which was interpreted as a shear resistance value obtained at the final shearing. Evaluation of the reduction of the shear strength of the soil was determined using the Haefely's ratio (1965):

$$
\lambda_{B}=\frac{\tau_{r}}{\tau_{p}}
$$

where:

$\tau_{r}-$ residual strength;

$\tau_{p}$ - maximum strength.

\section{TEST RESULTS AND THEIR ANALYSIS}

The results of the strength parameters tests were set together in the Table 2. In general, the values of the angle of internal friction and cohesion calculated at the maximum value of the shear resistance (so-called peak parameters) fall within a relatively wide range. The obtained values of the angle of internal friction are close to the values of this parameter given in the work of Borecka et al. (2006) for Tertiary clays, while the values of cohesion are smaller than those in the above-cited work, which may be due to the relatively low plasticity of the tested soils. On the other hand, some studies of tertiary clays (Wysokiński 2006) indicate that the these soils in a compacted state may be characterized by the values of cohesion about $20 \mathrm{kPa}$. The results of the tests of clayey soils located within the Magura unit, from the landslides in Wapienne and Sękowa (Bednarczyk 2005) show that those deposits at the liquidity index $0.03-0.13$ are characterized by the values of the angle of internal friction and cohesion respectively in the range of $12.5-29.0^{\circ}$ and $17.1-31.0 \mathrm{kPa}$. In turn, the tests of Zabuski et al. (2003) carried out at the landslide Kawiory in Szymbark near Gorlice for clayey soils of the moisture content values similar to 
TABLE 2. Peak and residual values of the shear strength parameters obtained after three series of shearing

\begin{tabular}{|l|c|c|c|c|}
\hline \multirow{2}{*}{ Origin of soils } & \multicolumn{2}{|c|}{ Peak shear strength } & \multicolumn{2}{c|}{ Residual shear strength } \\
\cline { 2 - 5 } & $\begin{array}{c}\text { angle of inter- } \\
\text { nal friction, } \\
\varphi_{\text {peak }}\left[^{\circ}\right]\end{array}$ & $\begin{array}{c}\text { cohesion, } \\
c_{\text {peak }}[\mathrm{kPa}]\end{array}$ & $\begin{array}{c}\text { angle of inter- } \\
\text { nal friction, } \\
\varphi_{r}\left[{ }^{\circ}\right]\end{array}$ & $\begin{array}{c}\text { cohesion, } \\
c_{r}[\mathrm{kPa}]\end{array}$ \\
\hline Ciężkowice & 19.7 & 22.9 & $14.2(13.1)^{*}$ & $5.6(4.2)$ \\
\hline Owczary / soil 1 & 14.4 & 29.7 & $12.9(7.4)$ & $6.7(12.3)$ \\
\hline Owczary / soil 2 & 15.4 & 21.8 & 11.4 & 5.8 \\
\hline Ropica Polska & 11.2 & 19.3 & 9.0 & 5.9 \\
\hline Szymbark / Maślana Góra & 24.1 & 15.8 & $14.9(9.8)$ & $7.6(8.2)$ \\
\hline Szymbark / Wiatrówki & 25.9 & 26.0 & 11.5 & 5.0 \\
\hline
\end{tabular}

*In brackets values obtained after six series of shearing.

these obtained in this work have shown that those deposits can have a very wide range of parameter values characterizing the shear strength, which in the case of the angle of internal friction ranged from 9.8 to $20.6^{\circ}$, in the case of cohesion $17.7-75 \mathrm{kPa}$.

A characteristic phenomenon observed during the first series of shearing of the soil samples was rapid increase in the shear resistance, which occurred in the initial phase of the test, and then systematically decreased until the end of the test. During subsequent series of shearing, recorded values of the shear resistance would increase initially and then stabilize in the final phase of the study; at the following series of tests, the obtained values of shear resistance were getting smaller. The shear strength values obtained after a few series of shearing were clearly smaller than the peak shear strength values. The calculations of the values of the Haefeli's coefficients (Table 3) showed that after three series of shearing, the values of the shear resistance were two or even three times smaller, with the greatest reduction achieved for the soil from the slope of Wiatrówka in Szymbark. The obtained changes in the shear resistance were reflected in the values of the strength parameters. The values of the residual angle of internal friction of the tested soils (Table 2) ranged from 9.0 to $14.9^{\circ}$, and thus were about $1.5-14.6^{\circ}(10-56 \%)$ smaller than peak values of these parameters. In turn, the values of the residual cohesion were equal 5.3-7.6 kPa, and they were twice, or even five times smaller than the peak values of these parameter.

The results of the tests of the soil samples subjected to six series of shearing are interesting. The obtained data (Fig. 1) show that the increase in the number of shearings resulted in the reduction of the angle of internal friction, while in the case of two soils it is visible that after the third shearing, an increase in cohesion occurred, which, according to Borecka et al. (2006) may be the result of reconstruction of a so-called water-colloidal cohesion caused by plasticising the soil due to the supply of the water surrounding the apparatus box to the soil sample. The calculated values of 
TABLE 3. Values of Haefeli's index obtained after three series of shearing

\begin{tabular}{|l|c|c|c|c|c|c|}
\hline \multirow{2}{*}{$\begin{array}{l}\text { Normal } \\
\text { stress [kPa] }\end{array}$} & \multicolumn{7}{|c|}{ Origin of soil } \\
\cline { 2 - 7 } & Ciężkowice & Owczary 1 & Owczary 2 & $\begin{array}{c}\text { Ropica } \\
\text { Polska }\end{array}$ & $\begin{array}{c}\text { Szymbark } \\
\text { Má́lana } \\
\text { Góra }\end{array}$ & $\begin{array}{c}\text { Szymbark } \\
\text { Wiatrówki }\end{array}$ \\
\hline 25 & 0.36 & 0.35 & 0.40 & 0.38 & 0.61 & 0.23 \\
\hline 50 & 0.42 & 0.45 & 0.46 & 0.48 & 0.50 & 0.36 \\
\hline 75 & 0.53 & 0.48 & 0.46 & 0.52 & 0.59 & 0.30 \\
\hline 100 & 0.53 & 0.51 & 0.54 & 0.57 & 0.52 & 0.36 \\
\hline 125 & 0.56 & 0.54 & - & 0.56 & 0.56 & 0.34 \\
\hline 150 & 0.55 & 0.65 & 0.58 & 0.61 & 0.60 & - \\
\hline Mean & 0.49 & 0.49 & 0.49 & 0.52 & 0.56 & 0.32 \\
\hline
\end{tabular}

the Haefeli's coefficients after six shearings of the samples were about $17 \%$ smaller than the values of this parameter obtained after the third shearing.

Overall, the obtained results of the tests indicate that the formation of the zone of weakness in the soil due to repeated shearings first of all affects the reduction of the forces of mutual attraction between soil particles which has the effect of lowering the value of cohesion. According to some researchers, as a result of formation of residual strength in soil, the destruction of the forces of mutual attraction occurs, which is equivalent to the assumption that the residual strength is characterized merely by the angle of internal friction. According to Skempton (1964), and also as the results of tests by Tiwari et al. (2005), Carrubba and Del Fabbro (2008) show, there happen cases of small residual cohesion values.

Therefore, while interpreting the results of the residual strength tests one can meet the various methods of description of this strength characteristics. For
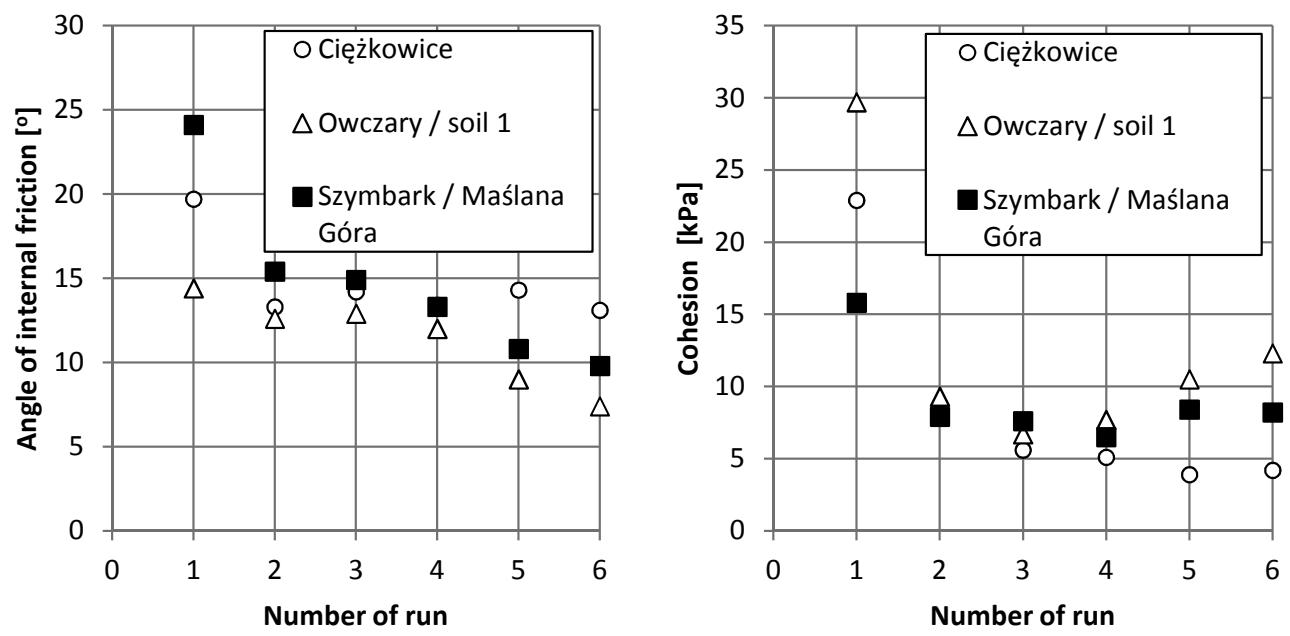

FIGURE 1. Values of shear strength parameters of the tested soils vs. number of runs 
example, according to engineering practice widespread in the United States, there is used a linear description of the strength characteristics of the soil, assuming at the same time that the cohesion is equal to zero, and the value of the residual angle of internal friction results from the back analysis. In turn, according to Japanese criteria (Tiwari et al. 2005), it is assumed that the residual cohesion corresponds to the average depth of the slip plane, and the value of the residual angle of internal friction is determined by the back analysis. There is also a method used, among others, by Stark and Eid (1994), Mesri and Shahien (2003), Dewoolkar and Huzjak (2005), which assumes that the residual cohesion is taken as equal to zero, and the angle of internal friction is a value depending on the magnitude of normal stresses:

$$
\phi_{r}=\operatorname{arctg}(\tau / \sigma)
$$

where:

$\tau$ - residual shearing strength of the soil; $\sigma-$ normal stress.

While using the above equation, the obtained values of the residual shear strength of the tested soils were described by the values of the angle of internal friction, which were made dependent on the magnitude of normal stresses (Fig. 2). The relations obtained indicate that with the increase of normal stress the values of the angle of internal friction are reduced, whereby at the load corresponding to $100 \mathrm{kPa}$ relative stabilization of the value of the angle of internal friction can be noticed. Similar relationships are presented, among others, in the work of Tiwari et al. (2005) and the results of the Carubby and Del Fabro (2014) showed that the residual values of the angle of internal friction were relatively constant already at the stresses of about $50 \mathrm{kPa}$. The results of the statistical calculations showed that the maximum correlation between the analysed values was obtained using a power function.

Another proposal of a nonlinear description of the residual strength is the equation presented in the work of Mesri and Shahien (2003):

$$
\tau=\sigma \cdot \operatorname{tg}\left(\phi_{r}^{100}\right) \cdot[100 / \sigma]^{1-m}
$$

where:

$\varphi_{r}{ }^{100}$ - residual angle of internal friction at the normal stress of $100 \mathrm{kPa}$; 1- $m$ - gradient of the function $\log$ [tg $\left.\left(\varphi_{r}^{\mathrm{x}}\right) / \operatorname{tg}\left(\varphi_{r}{ }^{100}\right)\right]$ versus $\log \left(100 / \sigma_{\mathrm{r}}^{\mathrm{x}}\right)$; $\varphi_{r}{ }^{\mathrm{x}}$ - the residual value of the angle of internal friction determined from the equation (1) at the load $\left(\sigma_{\mathrm{r}}^{\mathrm{x}}\right)$.

Another way of the non-linear description of the shear strength, simplified in relation to the method described above is the equation of Lade (2010), which the author intended mainly for the description of the strength of non-cohesive soils:

$\tau=a \cdot p_{a} \cdot\left(\frac{\sigma}{p_{a}}\right)^{b}$

where:

$p_{a}-$ atmospheric pressure (acc. to Lade it can be assumed as equal to $100 \mathrm{kPa}$ ); $a, b$-constants of the equation, depending on the soil.

Table 4 shows the parameters of the equations (2) and (3) obtained for the tested soils. The calculation results obtained using both methods are conver- 

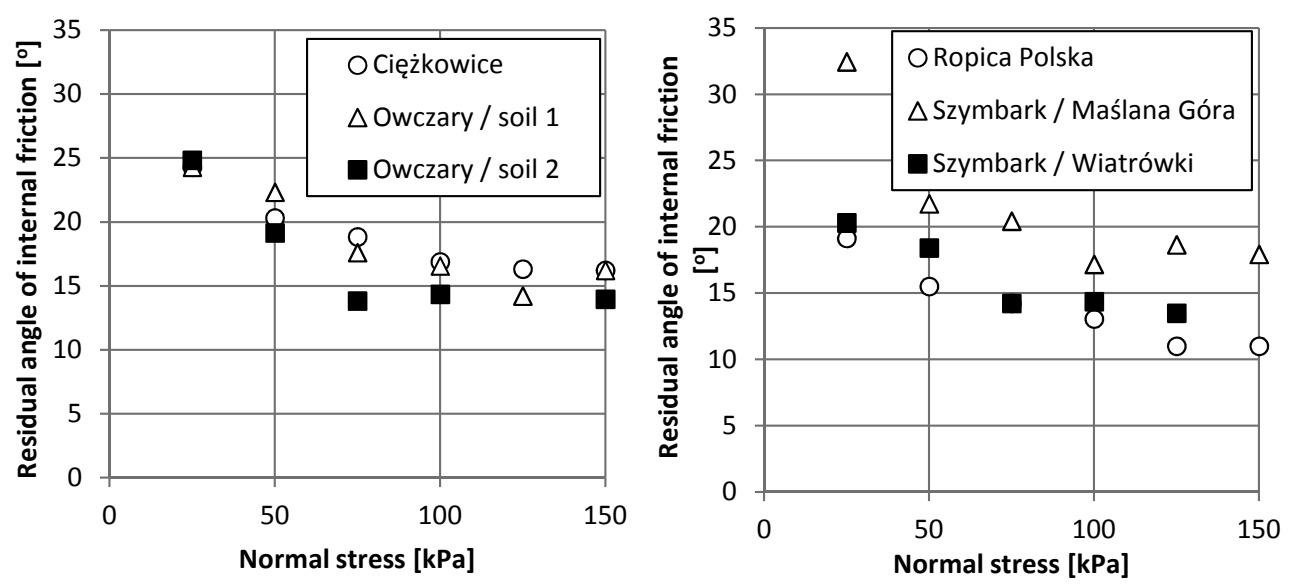

FIGURE 2. Residual angle of internal friction versus normal stress

TABLE 4. Values of parameters of (3) and (4) equations estimated for the tested soils

\begin{tabular}{|l|c|c|c|c|}
\hline \multirow{2}{*}{ Origin of soil } & \multicolumn{2}{|c|}{ Parameters of equation (3) } & \multicolumn{2}{c|}{ Parameters of equation (4) } \\
\cline { 2 - 5 } & $\varphi_{r}{ }^{100}$ & $1-m$ & $a$ & $b$ \\
\hline Ciężkowice & 17.4 & 0.256 & 0.31 & 0.74 \\
\hline Owczary / soil 1 & 16.8 & 0.312 & 0.30 & 0.69 \\
\hline Owczary / soil 2 & 14.6 & 0.377 & 0.26 & 0.62 \\
\hline Ropica Polska & 12.5 & 0.331 & 0.22 & 0.67 \\
\hline Szymbark / Maślana Góra & 19.0 & 0.372 & 0.35 & 0.63 \\
\hline Szymbark / Wiatrówki & 14.2 & 0.288 & 0.25 & 0.71 \\
\hline
\end{tabular}

gent. Figure 3 shows the comparison of the tests results for some samples described by the Coulomb's linear equation and the proposal of Lade.

To determine the practical significance of the obtained results of the conducted tests, stability analysis for non-saturated and partly saturated slope with a flat slip surface was performed. Calculations were made for three variants of the soil shear strength: based on the maximum parameters, residual ones obtained directly from the tests (after the third shearing of the samples) and the strength described by the equation (3). It was assumed that slipping surface was 2 $\mathrm{m}$ below terrain level and the slope inclination was equal $15^{\circ}$.

The results of stability calculations (Table 5) have shown that the stability coefficients determined using the maximum strength parameters are much larger than the values of this parameter obtained from the calculations on the bases of the values of the residual strength. In turn, comparing the results of stability calculations based on the residual parameters obtained directly from the tests and described with the formula (3), it was found that in the case of the non-saturated slope, the stability coefficient values are very similar. However, 

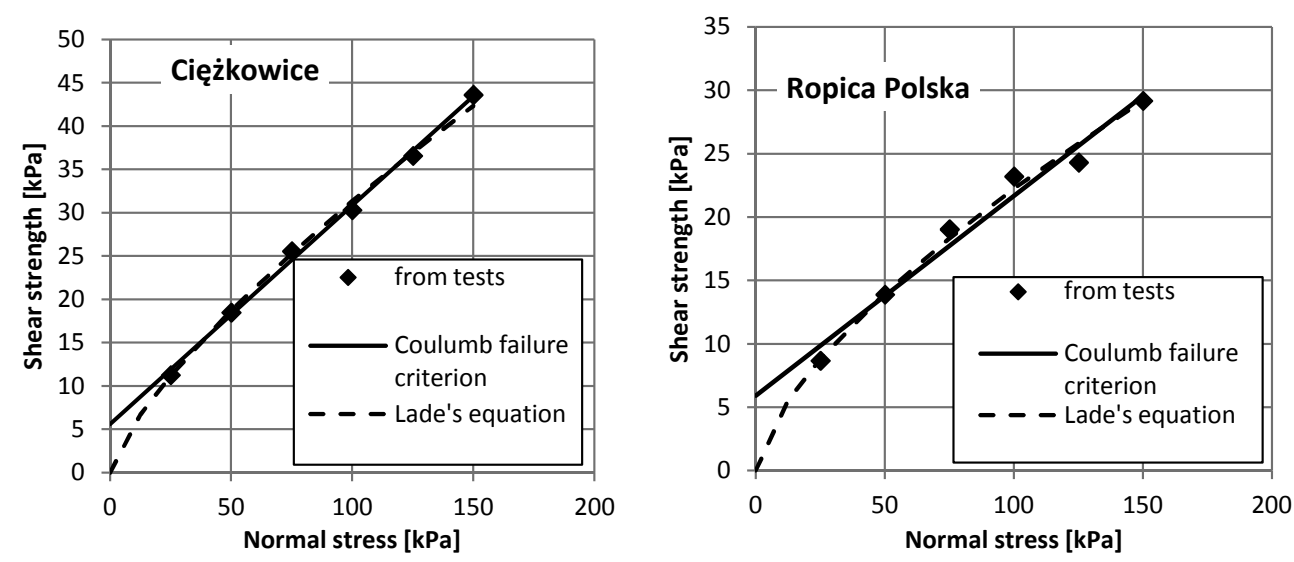

FIGURE 3. Comparison of linear Coulomb failure criterion and Lade's equation with experimental results for exemplary soils

TABLE 5. Results of slope stability calculations for hypothetic slope in relation to the type of shear strength parameters determination method

\begin{tabular}{|l|c|c|c|}
\hline \multirow{2}{*}{ Origin of soil } & \multicolumn{3}{|c|}{ Values of safety factor obtained for } \\
\cline { 2 - 4 } & \multirow{4}{*}{$\begin{array}{c}\text { peak shear strength } \\
\text { parameters }\end{array}$} & \multicolumn{2}{|c|}{ residual parameters } \\
\cline { 2 - 4 } & \multicolumn{3}{|c|}{ Dry slope (failure plane depth 2 m) } \\
\hline determined from tests & $\begin{array}{c}\text { estimated as a function } \\
\text { of normal stress [eq. (3)] }\end{array}$ \\
\hline Owęzowice & 3.87 & 1.56 & 1.54 \\
\hline Owczary / soil 1 & 4.08 & 1.56 & 1.55 \\
\hline \multicolumn{2}{|c|}{ Partly saturated slope (failure plane depth 2 m, ground water table depth $1 \mathrm{~m}$ ) } \\
\hline Ciężkowice & 4.48 & 1.31 & 1.22 \\
\hline Owczary / soil 1 & 4.54 & 1.34 & 1.27 \\
\hline Owczary / soil 2 & 3.77 & 1.16 & 1.19 \\
\hline
\end{tabular}

in the case where the slope was partially saturated, less favourable stability coefficient values were obtained by choosing the second method of estimating the residual parameters. So it can be stated that at low values of normal stress slope stability calculation results depends significantly on cohesion. Hence, in such cases more safer values of safety factor can be obtained assuming that residual shear strength is only described by angle of internal friction, which if is a function of normal stresses. In turn, analyzing the stability of slopes under normal stress from about $50 \mathrm{kPa}$ (cf. Fig. 3) it can be deduced that the two ways of estimating the residual strength should give similar values of the stability coefficients.

Determination of the residual strength is time-consuming and therefore there are sought correlations between the values of the residual angle of internal 
friction and the other physical characteristics and mineral composition of soils (Colotta et al. 1989, Stark and Eid 1994, Wesley 2003, Tiwari and Marui 2005). In the analysis, there were taken into consideration the content of the clay fraction, liquid limit, plasticity index and the empirical formula proposed in the works of Colotty et al. (1989) and Dewoolkar and Huziak (2005). The results of calculations were compared with the values of the angle of internal friction determined directly from the tests (see Table 2) and defined by the equation proposed by Lade (2010) and recalculated for the stress values of $100 \mathrm{kPa}$. The results of the analyses (Fig. 4) showed that the residual values of the angle of internal friction of the tested soils are the best correlated with the values of the plasticity index. the zone of weakness in the plane of shearing, leading to a distinct reduction in the initial (maximum) shear strength. It was shown, in the case of the tested clayey soils, that the residual strength obtained after three series of shearing was equal on average $50 \%$ of the maximum shear strength of the soil.

2. The values of the residual strength after six shearings accounted for an average of $43 \%$, and in the extreme case even $37 \%$ of the maximum shear strength of the soil. Therefore, the obtained results indicate that in order to determine the residual strength it seems reasonable to carry out at least 5-6 series of shearing of the same soil sample.

3. Direct interpretation of the results of the residual shear strength tests has

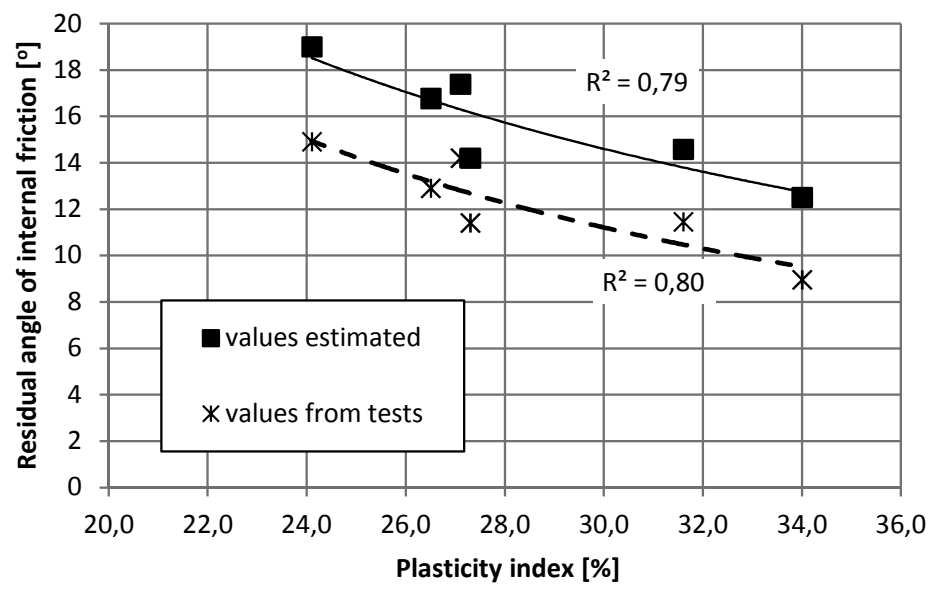

FIGURE 4. Residual angle of internal friction versus plasticity index

\section{CONCLUSIONS}

On the basis of the carried out tests and their analysis it was stated that:

1. Shearing the same soil sample several times contributes to the formation of shown that the soils are characterized by the insignificant cohesion, which is not fully consistent with the theory, but it occurres in the case of a linear description of the shear strength of soils. It has appeared from the stabil- 
ity calculations that this type of approach, in the case of small values of normal stresses, gives more favourable calculation results than the use of the assumption that the residual strength is described nonlinearly assuming the absence of the residual cohesion.

4. It has been shown, that the values of the residual angle of internal friction are relatively well correlated with the plasticity index of the tested soils. In contrast, there was no clear correlation between the residual strength and the other index properties of the tested soils.

\section{REFERENCES}

BEDNARCZYK Z. 2005: Examples of the mass movement investigations in different types of deposits. Proceedings of the Conference "Mass movement hazard in various environments". Polish Geological Institute Special Papers 20, 14-26.

BORECKA A., HERZIG J., KACZMARCZYK R., WOŹNIAK H. 2006: Właściwości fizykomechaniczne wybranych gruntów spoistych ze zboczy wyrobiska KWB „Bełchatów” (Phisical and mechanical properties of cohesive soils from the slope of the working in the Brown Cole Mine „Bełchatów”). Zeszyty Naukowe Politechniki Białostockiej, Budownictwo 28, 39-50 [Engl. summ.]

BORECKA A., KACZMARCZYK R. 2008: Czynniki wpływające na parametry wytrzymałości na ścinanie w strefach zagrożeń osuwiskowych na przykładzie odkrywek węgla brunatnego (Factors influencing shear strength parameters in the zones of landslide threats exemplified by brown coal open pits). Geologia 34(4), 709-719 [Engl. summ.]
CARUBBA P., Del FABBRO M. 2008. Laboratory investigation on reactivated residual strength. Journal of Geotechnical and Geoenvironmental Engineering 134(3), 302-315.

CIESZKOWSKI M., KOSZARSKI A., LESZCZYŃSKI S., MICHALIK M., RADOMSKI A., SZULC J. 1987. Szczegółowa Mapa Geologiczna Polski. Arkusz Ciężkowice, PIG, W-wa (Detailed Geological Map of Poland. Sheet Ciężkowice ) [Engl. summ.].

COLOTTA T., CANTONI R., PAVESI U., RUBERL U., MORETTI P.C. 1989: A correlation between residual friction angle, gradation and the index properties of cohesive soils. Géotechnique 39(3), 343-346.

DEWOOLKAR M.M., HUZJAK R.J. 2005: Drained residual strength of some claystones from Front Range, Colorado. Journal of Geotechnical and Geoenvironmental Engineering 131(12), 1543-1551.

HAEFELI R. 1965: Creep and progressive failure on snow, soil rock and ice. Proceedings of 6th International Conference on Soil Mechanics and Foundation Engineering 3, 134-148.

LADE P.V. 2010: The mechanics of surficial failure in soil slopes. Engineering Geology 114, 54-64.

MESRI G., SHAHIEN M. 2003: Residual shear strength mobilized in first-time slope failures. Journal of Geotechnical and Geoenvironmental Engineering 129(1), 12-31.

NOWAKOWSKI J., NABORCZYK J., PETRASZ J., SALA A. 1999: Instrukcja obserwacji i badań osuwisk drogowych (Instruction of monitoring and investigation of road landslides). GDDP, 72 [Engl. summ.].

PN-EN ISO 14688-2:2004. Badania geotechniczne. Oznaczanie i klasyfikowanie gruntów (Geotechnical Investigation and testing - Identification and classification of soil. Part 2 - Principles for a classification]. Warszawa [Engl. summ.]. 
PKN-CEN ISO/TS 17892-10. Badania geotechniczne. Badania laboratoryjne gruntów. Cz. 10. Badanie w aparacie bezpośredniego ścinania (Geotechnical Investigation and testing - Identification and classification of soil. Part $10-\mathrm{Di}-$ rect shear tests). PKN, Warszawa [Engl. summ.].

PN-86/B-02480. Grunty budowlane. Określenia, symbole, podział i opis gruntów (Building soils. Nomenclature, symbols, classification and description of soils). PKN, Warszawa [Engl. summ.].

RĄCZKOWSKI W. 2007: Zagrożenia osuwiskowe W polskich Karpatach. (A landslides threats in Polish Carpathians). Proceedings of Konf. "GEOZAGROŻENIA - zmniejszanie ryzyka, podnoszenie świadomości" - V Międzynarodowe Targi Geologiczne, Warszawa [Engl. summ.]

SKEMPTON A.W. 1964: Long-term stability of clays slopes. Géotechnique 14(2), 75-101.

SMOLTCZYK U. 2002: Geotechnical engineering handbook. Vol. 1. Fundamentals. Ernst \& Sohn Verlag, Berlin.

STARK T., EID H. 1994. Drained residual strength of cohesive soils. Journal of Geotechnical Engineering 120 (5), 856$-871$.

STARK T., HUSSAIN M. 2010: Shear strength in preexisting landslides. Journal of Geotechnical and Geoenvironmental Engineering 136(7), 957-962.

TIWARI B., BRANDON T.L., MARUI H., TULADHAR G.R. 2005: Comparison of residual shear strengths from back analysis and ring shear tests on undistrurbed and remolded specimens. Journal of Geotechnical and Geoenvironmental Engineering 131(9), 1071-1079.

TIWARI B., MARUI H. 2005: A New method for the correlation of residual shear strength of the soil with mineralogical composition. Journal of Geotechnical and Geoenvironmental Engineering 131 (9) 1139-1150.
WARCHOŁ M. 2007: Architektura depozycyjna warstw magurskich w strefie Siar na południe od Gorlic (płaszczowina magurska, polskie Karpaty zewnętrzne) [Depositional architecture of the Magura Beds from the Siary zone, south of Gorlice (Magura Nappe, Polish Outer Carpathians)]. Przeglad Geologiczny 55(7), 601-610 [Engl. summ.].

WESLEY L.D. 2003: Residual strength of clays and correlations using Atterberg limits. Géotechnique 53(7), 669-672.

WYSOKIŃSKI L. 2006. Ocena stateczności skarp i zboczy (Assessment of stability of embankment and slopes). Instytut Techniki Budowlanej, Warszawa, 78 [Engl. summ.].

ZABUSKI L., GIL E., RACZKOWSKI W., WÓJCIK A. 2003: Badania reprezentatywnego procesu osuwiskowego w masywie fliszu karpackiego - osuwisko eksperymentalne w Beskidzie Niskim (Investigations of representative landslide in the Carpathian flysch - experimental landslide in Beskid Niski Mts.). IBW, Gdańsk, 53 [Engl. summ.].

Streszczenie: Badania wytrzymałości na ścinanie gruntów ilastych z okolic Gorlic i Ciężkowic. W pracy przedstawiono wyniki badań wytrzymałości maksymalnej i resztkowej sześciu gruntów ilastych pochodzących z terenów osuwiskowych okolic Gorlic oraz Ciężkowic. Badania przeprowadzono w aparacie bezpośredniego ścinania na próbkach o przekroju $60 \times 60 \mathrm{~mm}$, stosując co najmniej trzykrotne ścinanie próbek gruntu. Prędkość ścinania wynosiła $0,1 \mathrm{~mm} \cdot \mathrm{min}^{-1}$, a zakres odkształceń poziomych próbek wynosił $20 \%$. Wyniki badań wykazały, że wielokrotne ścinanie gruntu powoduje znaczne zmniejszenie jego wytrzymałości na ścinania, co powoduje znaczące zmiany spójności, a mniejsze kąta tarcia wewnętrznego. Wykazano, że trzykrotne ścięcie powoduje zmniejszenie początkowej wytrzymałości na ścinanie o około $50 \%$, a po kolejnych trzech seriach ścieć stwierdzono dalsze około 15\% zmniejszenie wytrzymałości. Badania wykazały również, że stosując liniowe równanie wytrzymałości Coulomba, analizowane grunty wykazują niewielką spójność resztkową. Stąd też do opisu 
charakterystyki wytrzymałości resztkowej zastosowano dwa równania nieliniowe zaproponowane przez Mesriego i Shaniena (2003) oraz Lade'a (2010), które jak wykazały obliczenia prowadzą do tych samych rezultatów. Wykazano również, że zastosowanie nieliniowej charakterystyki wytrzymałości resztkowej daje przy małych wartościach naprężeń normalnych bardziej niekorzystne wyniki obliczeń stateczności w stosunku do metody opracowanej na podstawie liniowej charakterystyki wytrzymałościowej uwzględniającej obecność spójności resztkowej.
Stowa kluczowe: wytrzymałość resztkowa, grunty ilaste, Karpaty Zewnętrzne

\section{Authors' address:}

Tymoteusz Zydroń

al. Mickiewicza 24/28, 30-059 Kraków

Poland

e-mail: t.zydron@ur.krakow.pl 